\title{
THE STRUCTURE OF THE DUTCH WASTE SECTOR AND IMPEDIMENTS FOR WASTE REDUCTION
}

\author{
Paulien de Jong and Maarten Wolsink \\ Department of Environmental Sciences, University of Amsterdam, Nieuwe Prinsengracht 130, \\ 1018 VZ Amsterdam, The Netherlands
}

(Received 11 September 1995, accepted in revised form 5 September 1996)

\begin{abstract}
The way in which organizations collect, treat and dispose of waste in The Netherlands frustrates the achievement of waste reduction goals. The possibility that directed modification of the structure of the waste sector may contribute to stimulating consumers (i.e. all waste producers using services from collectors) to limit the generation of waste at the source by means of source reduction, re-use and recycling, is the subject of research of which the first results are presented here. This article describes the structure of the Dutch waste sector and indicates impediments for waste reduction linked to it. The analysis starts with a categorization of organizations with vested interests in the handling of waste. The ways in which these organizations manage to gain influence on the manner in which waste is handled will be explained, as well as the mutual relationships between organizations. 1997 ISWA
\end{abstract}

Key Words-Municipal solid waste, waste market, waste sector, institutional impediments, waste reduction, sector structure, The Netherlands.

\section{Introduction}

Compared to other European states, the volume of waste flows in The Netherlands is enormous. Within the European Union the average annual solid waste production of households and industries is $363 \mathrm{~kg}$ per capita, but the Dutch are the largest waste generators: their average production is $497 \mathrm{~kg}$ per capita (Eurostat 1993). Although some scepticism about the significance of these kind of data is justified, a significant trend should be recognized. Generally, the volume of solid waste is still increasing. This should be a matter of great concern, because the primary objective of Dutch waste policy is source reduction and recycling the second.

Solid waste is an issue because of emissions to water, soil and air, the space needed for disposal facilities and the loss in terms of resources and energy. The aim of the Dutch national policy on waste management is to minimize the quantity of waste that has to be incinerated or dumped. Therefore, waste reduction has to be encouraged (10\% in 2000) combined with recycling (66\% in 2000). In the National Environmental Policy Plan Plus an overall goal is formulated for waste disposal (VROM 1990). The total amount of waste for disposal has to be reduced from 20 million tonnes per annum now (excluding dredging and manure) to 12 million tonnes in the year 2000. Disposal in landfills must be reduced from 17 million to 5 million tonnes per annum; landfilling of combustible waste will no longer be allowed after 2000 . 


\section{Interorganizational networks}

Although several activities have been initiated to fulfil the waste reduction goal, it is expected to be hard to achieve (RIVM 1993). In Dutch waste policy and research much attention has been paid to the formulation of targets and regulations and to the selection of policy instruments. The size and composition of waste streams is determined by several factors like demographic developments (population growth, household composition), economic developments (prosperity) and technological trends (mixing of materials). The fact that the size and composition of waste flows is also determined by the social context in which the removal and processing of waste takes place, is too often neglected. Nevertheless, this may be a highly significant factor, as an international multiple-case study shows, for example, that a powerful pro-incineration alliance frustrates the attempts to control and decrease the amount of waste (Gandy 1994a). ${ }^{1}$

In many ways, organizations, like companies, public services and authorities, have conflicting interests. Their objectives often conflict with the policy goal of waste reduction. The significance of organizational conditions for policy implementation is already recognized in other sectors. A comparison can be made with the energy sector, an interesting example of the significance of the structure of a sector for the implementation of (environmental) policy. The energy supply sector has to deal with the issues of energy saving and environmentally sound ways of production (IEA 1994). Electricity utilities, for example, either public or private, do not have a natural vested interest in reduction of electricity consumption. It reduces utility revenues which in turn causes higher consumer prices (Johansen \& Hoog 1995). This raises the question of whether or not energy conservation and efficient end-use can be stimulated effectively by the energy supply companies (Tellegen \& Gilijamse 1995). Particularly, electricity utilities have experimented with Demand Side Management (DSM) and some of them actually achieved energy savings (Nadel 1992). However, in the analysis of Johansen \& Hoog the perspectives of utilities and other interest groups in DSM are analysed, resulting in extensive list of interests (either positive or negative for DSM) that are mainly determined by structural factors. A comparison with the energy sector is interesting for yet another reason. ${ }^{2}$ In many countries the interdependency of the waste and energy sectors is increasing fast. The rise of waste-to-energy facilities is one important factor. The fast growing involvement of energy utilities in financial investments for waste facilities is another significant trend (Benzler et al. 1995).

In general, policy has to be implemented by other actors than the policy formulating bodies. These actors have objectives and interests, which often differ from those of the policy makers. They try to find ways to serve their own interests and they have the capability to frustrate the goal achievement of others. For an analysis of whether implementation of a policy is possible, and what the results of the attempts to implement the policy will be, the structure of the policy field must to be taken into account (Pressman \& Wildavski 1984). The structure of interorganizational relations and the vested interests of the actors in the field play an important role in determining the success of any policy. This structure is important with regard to both the formulation of a policy, as well as its implementation. Policy is the result of a process in which

\footnotetext{
${ }^{1}$ Gandy uses the terms of pre- and post consumer recycling (Gandy 1994a). In many cases pre-consumer recyling is part of waste reduction. Recycling within the firm is even a form of source reduction, as the recycled compounds stay within the production process and by definition cannot be called "waste".

${ }^{2} \mathrm{~A}$ comparison between the waste and electricity sector is part of our project but is not discussed here (see De Jong \& Slingerland 1996).
} 
coalitions of actors are influencing goals, instrumental choices, control mechanisms, etc. (Sabatier \& Jenkins-Smith 1993). Therefore, an evaluation of the waste reduction policy requires an analysis of vested interests, organizational relations and potential coalitions. In The Netherlands there are numerous organizations, both public and private, that try to influence the ways and the extent to which solid waste is handled. Most organizations (companies, public services, authorities) participating in the Dutch waste sector have no interest in limiting waste streams or in altering the kind of waste that has to be processed or disposed of. Intentions may be different, as well as ways of gaining influence. A private waste collecting organization for example tries to make money out of the service it provides, whereas municipalities may earn money as a result of their task to take responsibility for the public interest, as is dictated by legal obligations.

The best way to gain insight into the structure of the waste sector and to understand its dynamics, is to regard the organizations as linked in an interorganizational network. A characteristic of such a network is the fact that the individual objectives of the organizations participating in the network are more important than the objective of the network (Godfroy 1990). The organizations inside the network primarily try to fulfil their own needs and behave in conformity with their own objectives and interests. The main reason why organizations try to establish relations with other organizations is that they are often dependent on others to fulfil their objectives. Organizations in the waste sector try to influence the circumstances under which the removal, processing and disposal of solid waste takes place, which can either be interpreted as an attempt to become more powerful, or alternatively as an attempt to prevent others from becoming powerful in the network.

\section{Objectives and method}

The objectives of this article are:

(1) To describe the structure of the Dutch waste sector; and

(2) To indicate the barriers for waste reduction.

Relationships and the interdependency which they express become manifest in several ways. There is a wide range of transactions, from those that take place between two or more organizations, to those relations that are built in order to gear co-operative activities or form coalitions against other organizations. There are many kinds of transactions: exchanging information, exchanging money, sharing experiences. In the waste sector, owning and dealing with waste is one of the key relations. The structure of the waste sector is formed by the sum of existing relations between the organizations.

The research started with gathering data about all types of relations by investigating files of organizations, official policy documents and research reports of all organizations named in Table 1 and Fig. 2. As the first step the key actors were identified with these documents and their relations were established. In the next step the interests linked to the relationships and the position of the organizations in the network were established. The data are of a principally qualitative nature.

In the following phase data were gathered by interviewing key persons within selected organizations. The description of the interorganizational structure was updated by adding missing data that were obtained by the interviews. The interviews were used in particular to validate the information resulting from the first phase. For this purpose, the twelve extensive interviews were held with key persons from organizations from all 
TABLE 1

Examples of organizations operating within the waste sector

\begin{tabular}{|c|c|c|c|c|}
\hline $\begin{array}{l}\text { Interest } \\
\text { group }\end{array}$ & Actors & $\begin{array}{l}\text { Representational } \\
\text { organization }\end{array}$ & $\begin{array}{l}\text { Intermediate } \\
\text { organization }\end{array}$ & $\begin{array}{l}\text { Consultation } \\
\text { between interests }\end{array}$ \\
\hline \multirow[t]{2}{*}{ Consumers } & households & Consumer Assoc. & & $\mathrm{AOO}$ \\
\hline & $\begin{array}{l}\text { businesses } \\
\text { municipal services }\end{array}$ & $\begin{array}{l}\text { Branches Assoc. } \\
\text { NVRD }\end{array}$ & BMRO & $\begin{array}{l}\text { STAF Target Group } \\
\text { KAB }\end{array}$ \\
\hline Collectors & private firms & VVAV & BMRO & STAF Target group \\
\hline Processors & private firms & Branch Associations & BMRO & STAF Target Group \\
\hline \multirow[t]{2}{*}{ Disposers } & public firms & VVAV & & $\mathrm{KAB}$ \\
\hline & private firms & VVAV & BMRO & STAF Target Group \\
\hline \multirow{3}{*}{$\begin{array}{l}\text { Authorities/ } \\
\text { administrative } \\
\text { levels }\end{array}$} & national & $\begin{array}{l}\text { VROM } \\
\text { DGM-Waste }\end{array}$ & $\mathrm{AOO}$ & $\begin{array}{l}\text { STAF Target Group } \\
\text { AOO }\end{array}$ \\
\hline & provinces & IPO & $\mathrm{AOO}$ & $\mathrm{AOO}$ \\
\hline & municipalities & VNG & $\mathrm{AOO}$ & $\mathrm{AOO}$ \\
\hline
\end{tabular}

AOO: Waste Management Council

BMRO: Office for Environment and Physical Planning (Employers Associations)

STAF: Steering Group Waste Materials of the BMRO

NVRD: Association of Waste- and Sanitation Experts

KAB: Chain-consultation Waste Managing Businesses

IPO: Inter-Provincial Consultation Body

VNG: Association of Dutch Municipalities

VROM DGM-Waste: Directory of Waste, Ministry of Housing, Physical Planning and Environment

categories included in Table 1. In particular, persons holding double positions were interviewed, for example in the Association of Municipalities and the Waste Management Council (VNG and AOO, see Fig. 2). In general the statements made in this article were validated in the interviews and in some cases they are based on information primarily coming from the interviews. If interviews are supporting statements, this will be indicated with $[I]$.

The waste sector is very broad. It includes hundreds of organizations. The scope of the given description is restricted to the national level and the conclusions about the structure of the Dutch waste sector and the impediments for waste reduction are written in terms of categories of organizations.

\section{The Dutch waste market and other participants in the waste sector}

Examples of different types of organizations are shown in Table 1 as representatives of the four main categories of interest. Public and private organizations that try to influence the conditions for the removal and processing of solid waste can be divided into seven groups, based on interests and activities which organizations have in common, and on the phase in the material life cycle on which their activities have impact (De Jong \& Wolsink 1993).

The first four categories (consumers, collectors, processors and disposers) are actors on the waste market. This part of the network can also be seen as an economic arena (Boons 1996). Beside the participants in the waste market other actors participate in the much broader waste sector. These actors are concerned with policy, or with supporting and influencing waste management policy (policy making authorities, research groups and consultancies, interest groups and umbrella organizations). 
The division of organizations in groups is not clear cut for all cases. Some organizations fit into one category only, while others have integrated more functions and fit into more categories. For example, there are waste collecting organizations that only pick up solid waste and bring it to the waste disposer with whom they have a long term contract. Other organizations see their task as more vertically integrated. They not only collect solid waste, but also process it themselves and sometimes even dispose of it.

\subsection{Participants on the waste market}

For participants on the waste market the main source of influence over the circumstances under which waste handling takes place is the fact that they control waste in a physical sense. As long as they own waste, others within the market or sector do not have much power over it.

\subsubsection{Consumers}

Solid waste, all discarded materials and products that have been sent to disposal facilities, is generated by different entities. These are the "consumers" of the services of organizations involved in collecting and removing waste. Consumers are households, institutions like schools, hospitals etc., and businesses from small enterprises to large industries.

Households are using the services of public waste collectors which in practice have a monopoly over household waste disposal. These services legally entail the separate collection of kitchen/garden waste and other municipal solid waste. The rate is set by the municipality, which is normally a flat monthly rate for the services provided, so there are no marginal cost rates. However some experiments are carried out with tariff differentiation based on volume, on frequency of offering or on weight. In the case of differentiation based on volume, households pay a fixed tariff and a variable one. The variable tariff depends on the size of the garbage container or the quantity of high priced special garbage bags that a household uses to offer waste. The experiments have yielded positive results; in several places a decrease of communal waste flow of $50-70 \%$ was reached (IPH 1994). One municipality, Haarlemmermeer, started with tariff differentiation based on frequency of offering. The experiment failed as a result of technical shortcomings. An experiment with differentiation based on automatic classification, weighting and registration of containers has been carried out in Oostzaan. The tariff consisted of a fixed rate and a variable price per kilogram. Each month a specified bill was sent. The experiment was so successful, that the municipality decided to retain both the tariff system and the collection method (Anonymous 1994). In municipalities with tariff differentiation the amounts of collected municipal solid waste and bio waste have decreased more than in communities that have no experience with differentiation of tariffs (Van Onck 1995). However, cases have also been observed of households taking their waste elsewhere in order to avoid costs ("waste tourism").

Institutions and small enterprises may offer their waste to municipal utilities, but they also have the opportunity to contract a private waste collector with a permit. With respect to these consumers the municipality has no monopoly. In practice the negotiated rates are part of the contracts and will depend on volume and type of waste.

Large companies or industries have to contract a private organization for collecting the waste. Since 1 January 1996 industrial enterprises need a permit from the provincial 
authority to do so. The permit prescribes separation of certain components and registration of weight, type and destination of the outgoing waste. Waste can only be handed over to collectors in possession of an allowance. The collecting organization is obliged to report acceptance of solid waste. With this legislation authorities try to gain control over waste shipment (Verhoog 1996).

All these "consumers" have in common that it is in their interest to get rid of the products and materials they consider useless, as cheap and efficiently as possible. Households have no direct influence on the price they pay. They are dependent on a monopolistic organization, whereas other consumers are free to choose their collectors and they negotiate on contract conditions.

\subsubsection{Collectors}

A waste collector is any organization, public or private, that collects and transports or transfers solid waste.

Municipalities have a legal obligation to collect solid waste at least once a week. They are also obliged to collect garden and kitchen waste separately. As agents of the public interest they have to develop and maintain a reliable, efficient and cost-effective system of solid waste removal and disposal. Disposal must take place for least costs in accordance with environmentally sound standards. Most Dutch municipalities carry out their own public service, only $17 \%$ of them hire private waste collectors to fulfil their legal commitment (CBS 1993).

The bulk of municipal solid waste generated by enterprises and industries, is collected by private organizations. These waste collectors earn profits by providing their services to municipalities and non-household consumers on the one hand, and on the other by finding ways to transport and deliver the collected waste to the cheapest disposal facilities. There are many of these private collectors. Some only operate at the local level, others on a national scale. Since the first half of the 1980s internationally operating companies have operated on the Dutch waste market.

\subsubsection{Waste processors}

Organizations involved in any kind of waste treatment are called waste processors. Before 1970 waste processing enterprises were motivated by the growing market for valuable secondary materials, like paper, textile, scrap and non-ferrous metals. Since 1970, the supply of secondary materials increased as a result of new technologies that created economically feasible options for recycling and re-use (Van Ruiten 1992). The demand for secondary materials has grown only recently. Stricter regulations, increasing costs for disposal and the expected shortage in landfill and incineration capacity have given a strong impulse to recycling and re-use. In particular, recycling garden and kitchen waste for horticulture, potting soil and public and private gardening became a large scale activity (Reijenga 1989). An additional market will be developed in the agricultural sector and possibly the green waste may also be used for fermentation (biogas).

In the sixties and seventies it was mostly private organizations that recognized the attractiveness of waste processing and made it their main activity. Later public wastecollecting organizations also expanded their activities in this direction and during the last five years waste disposers have entered into this field as well. The entry of disposers is due to the fact that they try to remain attractive for waste collecting organizations to supply waste to (De Rooy et al. 1996). 


\subsubsection{Waste disposers}

Waste disposers are those organizations that take care of landfilling and incineration. Although the exploitation of disposal sites is often in private hands, in most cases public authorities are the owners of the sites. In the waste sector public authorities have the legal task to develop and maintain a system of waste handling that services all locations in a reliable, cheap and efficient manner, in accordance with environmental standards. This task has become more complicated because of recent developments such as the growing quantities of waste and the tendency to stricter environmental standards (VROM 1989). These are a result of dioxin scandals and cases of contaminated soil that caused growing local opposition to new incinerating and landfilling facilities.

Higher investment levels and restricting pay-back periods have forced disposers to utilize their full capacity. Once the large investments for disposal, in particular incineration, have been made all capacity that is not fully utilized is costing huge amounts of money. Disposers try to avoid uncertainty by creating a sufficient and guaranteed incoming flow of waste. They try to force collectors and processors to deliver collected waste to them. One of the strategies is tying waste suppliers to long term contracts. The term of contracts with municipalities without an installation of their own varies from 10 to 25 years (AOO 1996). Another strategy is the extension of waste processing activities. Examples are known of disposers who not only incinerate, but also develop activities like composting, gasifying or decomposing materials that might be recycled at the plant.

\subsection{Other participants in the waste sector}

Beside the organizations participating on the waste market, some other groups of actors participate in the waste sector. First, there are governmental bodies that try to formulate and implement waste policy. Second, there are research groups and consultancies, that provide data and ideas to support the process of policy making. Third, there are those organizations which try to influence policy makers and political bodies.

Although these three groups of actors are not part of the waste market as they do not channel any waste flows themselves, their influence can be significant. The main source of influence on conditions for waste removal, handling and disposal stems from their legal authorisation to intervene, and their prescribed administrative tasks.

\subsubsection{Policy makers}

Public bodies on various levels have legally specified tasks and responsibilities regarding the formulation, operationalization and implementation of waste policy. This has originally been defined in the Waste Act of 1979, which was integrated in 1993 in the Environmental Management Act (EMA). It declares that every supplier of solid, nonchemical waste itself is responsible for waste handling (collecting, removal and disposal). The only category exempted from this responsibility is households: handling domestic waste is exclusively a task for municipalities. The EMA stipulates that all materials and products have to be handled in a certain order for environmental reasons: waste reduction should have priority over successively processing, incineration and landfilling. Since January 1996 it is no longer allowed to bring combustible waste to landfills.

On the national level the Ministry of Housing, Physical Planning and Environment (VROM) has to formulate waste policy goals in a National Policy Plan every four years. Figures for elaboration of the policy plan must be presented annually. The legal 
framework provides the national government with a wide range of possible measures. In practice, Dutch environmental policy is based on communicative instruments, such as information and persuasion campaigns, and on collective bargaining. A typical instrument developed in The Netherlands is the covenant, which involves establishing a deal between authorities and a sector in society, for example the packaging industry (WRR 1992). In 1988, the Minister of VROM issued a memorandum on waste reduction and recycling. In the memorandum, so-called priority waste streams are identified and volume reduction and recycling goals are set for each waste stream. Two principles are established as a basis for overall reduction of waste volumes and increased source reduction: re-use and recycling. The first is the concept of producer responsibility and the second is regulatory control, meaning the ultimate governmental right to limit or ban products or substances. In a typical Dutch expression it is "the stick behind the door", to punish actors that do not take their responsibility and sign a covenant.

Municipalities have an important executive task. They have statutory power, they are obliged to provide permits to consumers that generate waste, and they are also authorized to check that the laws are followed. Most municipalities have their own waste collecting service and they often invest in disposal plants, either alone or in cooperation with other municipalities.

According to the EMA the planning of disposal capacity has to be carried out on the regional level. Provinces are legally obliged to issue Provincial Waste Plans every five years. These plans must specify expected future waste flows within the provincial borders, as well as the kind and scale of the arrangements needed to take care of processing and disposal of the free coming waste. Beside their responsibility for planning and co-ordinating waste handling, provinces also provide permits for waste processing and disposal facilities.

All public bodies try to influence the conditions for removal and disposal. They try to limit the control over waste by private organizations on the waste market. In the eighties, waste became an item of both public and political concern. Quantities of waste were growing, environmental standards were tightened and landfilling combustible waste was banned, so a shortage of disposal capacity was anticipated. There also was the phenomenon of growing local opposition to new incinerating and landfilling facilities as a consequence of dioxin/scandals and cases of soil pollution. In 1989, a National Commission for Coordination of Waste Policy proposed an improved co-operation between different governmental bodies regarding waste policy and the planning of handling solid waste. The idea was made concrete with the creation of the Afval Overleg Orgaan (AOO). The official English translation of it is "Waste Management Council", which is rather confusing, as basically it is merely a consultation group. Literally the translation should be "Waste Consultation Body". The official policy agent is the Department of Environmental Management. However, in practice the AOO becomes more and more the body which formulates policy for the waste sector. The Department of Environmental Management asked the AOO to organize waste management on a national scale. Every three years a 10 -year programme has to be published, indicating required incineration and landfill capacity and determining where to build these facilities. Within a few years the $\mathrm{AOO}$ has developed into a central actor, as most major participants in the waste sector are involved in the consultation process within the AOO.

As the legal framework defines the authorized tasks of public authorities like collecting and disposal, they have to participate in the waste market and there they compete with 
private organizations. Some public authorities are developing a preference toward "demunicipalization" (Gandy 1994a). They have doubts about whether the utilities should remain public service corporations, or instead be privatized. Another urgent issue in the discussion concerns the level at which waste management should be handled; regionally or nationally.

\subsubsection{Research groups and consultancies}

Quantifying solid waste flows and determining their composition is essential for designing and implementing waste policy. Statistics on waste are needed for establishing trends, setting policy goals and evaluating policy. At all levels, planning of waste management is dependent of valid data. Many research groups and consultancies try to provide data and advise policy makers. Public bodies in this field are the Central Bureau for Statistics (CBS) and the Institute for Public Health and Environment (RIVM). CBS statistics are based on surveys among municipal waste utilities and private participants in the waste market. The studies of the RIVM are based on CBS data, but also on their own research, for example on the composition of household waste samples.

Provinces and municipalities have to gather data for their own planning. Mostly they rely on results of one-shot research commissions to private consultancies. There are several consultancies that have specialized divisions for waste issues. Some of them originate from business consultancies, some from accountancy firms, and some have their roots in environmental management consultancies. All research and consultancies rely heavily on the provision of data that have to be gathered from many private participants in the waste market.

\subsubsection{Interest groups and umbrella organizations}

A number of interest groups and umbrella organizations exist that sometimes represent collective interests of actors that are principally competitors. Some of these important actors are mentioned in Table 1. The VVAV for example, is the branch organization of private waste processors and public waste disposers. These have common interests in the formulation of waste policies, but they are competitors in the waste market.

The delegate role of interest groups and umbrella organizations was made easier when the AOO was installed. Representatives of households (consumer organizations), the foundation for nature and environment and umbrella organizations for employers are part of the AOO.

\subsection{Relations between organizations}

An inventory was made of all types of relations (section 3) between the different types of organizations (Table 1). The most significant relations are transactions of the trade on the waste market (flows of material and money). Figure 1 contains a schedule of the flow of waste and money in the economic arena.

Consumers hire collectors to free them from the burden of waste, and collectors provide that service in exchange for money. Crucial in this schedule is that the cash flows usually are going the opposite direction compared to the material flows, with one exception. Public collectors are paying private processors for the service of stripping and recycling parts of their waste. Private collectors, however, can be more selective and they concentrate on providing valuable materials to processors, so they do not pay themselves but they are paid for it. 


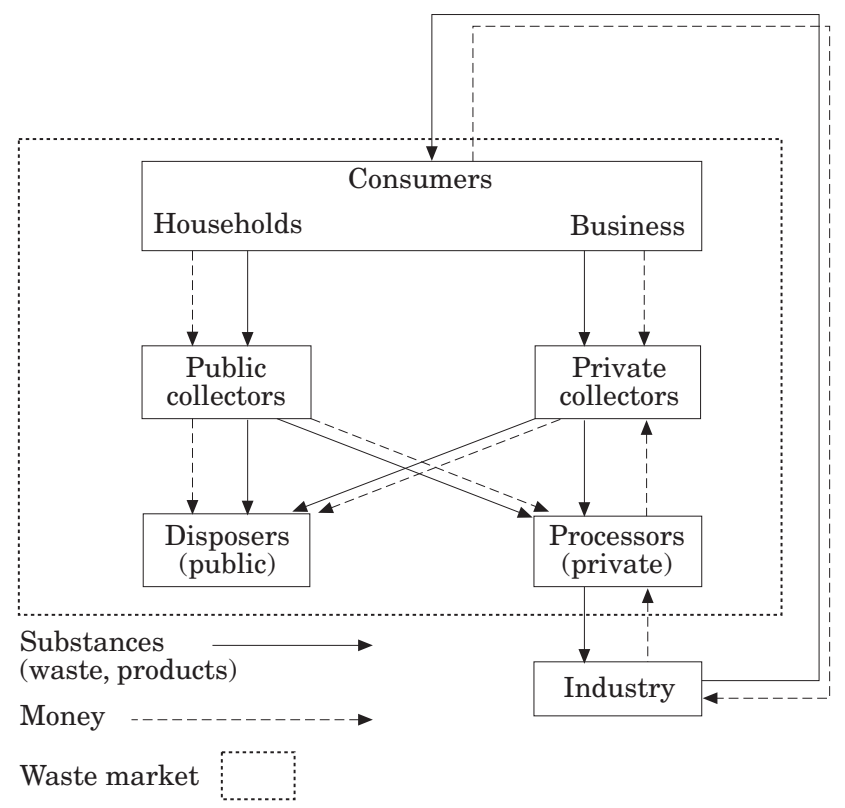

Fig. 1. Flow of waste and money in the waste market.

Relations and transactions between participants of the waste sector are: exchange of money, participation in other organizations (as do governmental bodies in processing or disposal facilities); legal interactions (like applying or granting permits); gearing activities or interchanging ideas and prospects. In the policy arena a number of consultative relations between the actors or actor groups, represented by their organizations, exist. The most important of these are represented in Fig. 2.

Motivations for entering into a relationship vary. They may be established for purposes of consultation, co-operation, competition or gearing activities. In many cases relations are an element of lobbying, or may even provide opportunities to participate in policy formulation. The formal principal actor in policy making is the ministry VROM, but actually much of the design comes from the AOO, which holds the central position in the network. Although the primary policy objective officially is waste reduction, in particular source reduction, the central policy actor AOO concentrates on planning policy and waste infrastructure, facilities that are mainly important for purposes linked to processing and disposal.

Concrete implementation of source reduction policy is more peripheral in the network. Information exchange and negotiations on conditions and targets for branches of industry takes place between the ministry (VROM DGM Waste), the organization of employers (BMRO) and businesses. In these target groups the provinces and municipalities and the interest groups do not participate. As a result, implementation of the primary policy objectives is not located at the centre of the network.

\section{Impediments for waste reduction in the structure of the waste sector}

\subsection{Linked interests}

One of the main structural problems is the entwining of interests in waste disposal and waste collection. Authorities find themselves in a paradoxical situation. Municipalities 


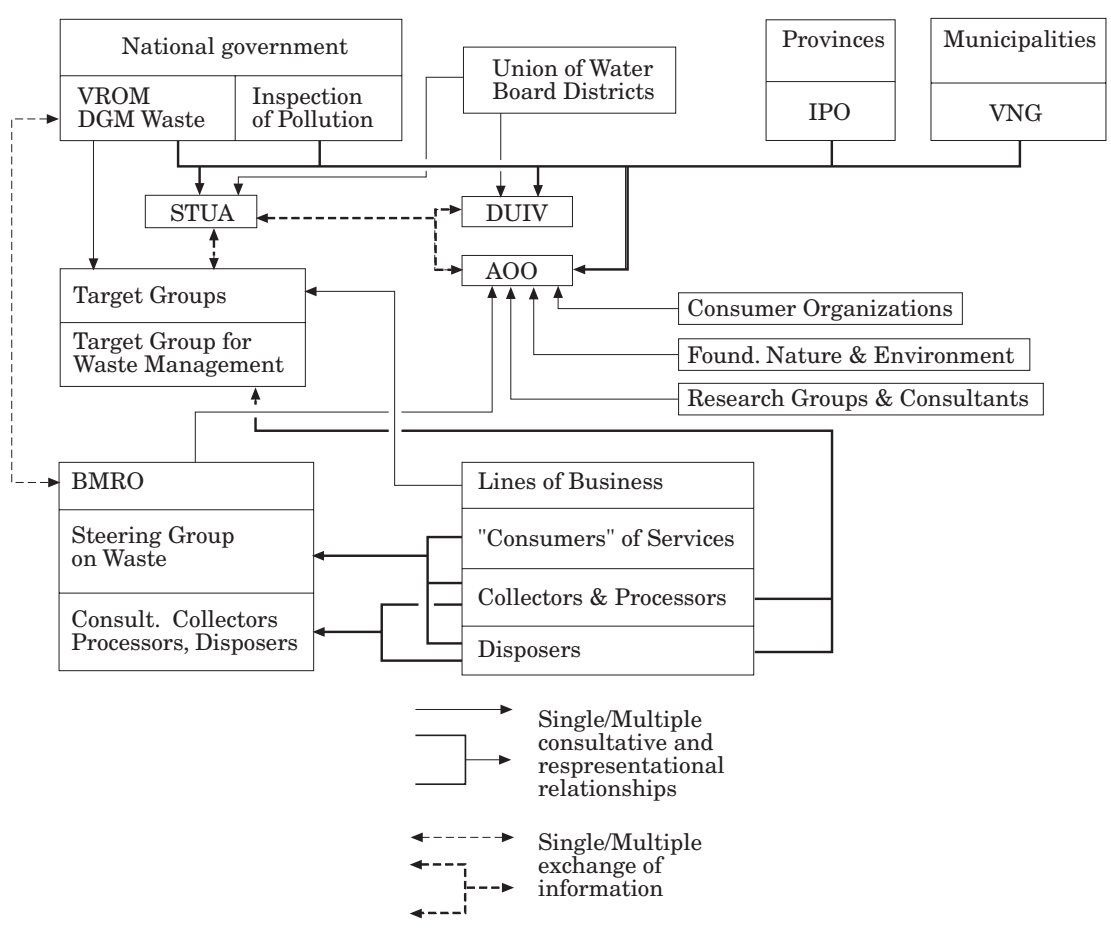

Fig. 2. Most significant relationships between organizations in the Dutch waste sector.

VROM DGM-Waste: Directory of Waste, Ministry of Housing, Physical Planning and Environment IPO: Inter-Provincial Consultation Body

VNG: Association of Dutch Municipalities

STUA: Steering Committee on Waste

DUIV: Administrative Consultation group on Waste

AOO: Waste Management Council

BMRO: Office for Environment and Physical Planning.

invest in disposal plants from the perspective of environmental hygiene. Acting in line with governmental waste policy, municipalities also invest in incinerators which have to be built in accordance with the present strict environmental standards. Once the facilities are operating the pay back times are highly depending on full utilization of capacity. The investments needed to build incineration plants are very large and take a long period of time to write off. Private organizations often consider financial risks to be excessive. Municipal authorities can pass on the corporate risks of building incineration plants to the residents, as they unilaterally set the tariffs for the collection of domestic waste. Once such investments have been made, any subsequent decrease in waste streams creates a deficit in the exploitation of the incineration plant.

Because of the investments in incinerators there is an interest in assurance of long term waste supply $[I]$. Waste processors attempt to guarantee a sufficient flow by tying collectors to long term contracts. Once incinerators are installed they start attracting waste $[I]$. Waste disposal, in particular incineration, must be considered to be an industry that uses waste as raw material, in particular when incineration is defined as a form of processing. This happens when future plants are linked to energy generation, although defining this as processing (or recycling) instead of disposal is questionable (Powell 1993). Rejected materials and products are primarily considered raw material 
for treatment with physical or chemical methods instead of recycling, re-use, composting or any other useful application. To continue the production process, sufficient raw material has to be available. For economic reasons, for both industries, processors as well as the disposers, the highest priority is an adequate supply (sufficient quantities, constant flows, reliable in the long term) of raw materials as input of their production process. Therefore they are looking for options that guarantee their input. As a rule, public bodies become tied down, while private enterprises remain free to change their supply from one processor to another (see Table 1). In this situation they may offer their waste to plants that offer generous rates for disposal (AOO 1994).

At the moment, the same can be said about regional authorities that want to get rid of waste but only against low prices. Since 1 January 1996 the landfill of combustible waste has been prohibited. Regions that do not have enough incineration capacity are exempted from this rule. This means that only five out of 12 provinces have an obligation to incinerate. In the other provinces, there is a surplus of waste compared to incineration capacity. Part of this waste is exported to provinces where there is enough capacity. For example, the northern provinces have committed themselves in 1995 to deliver 45000 tonnes of waste to the West and 25000 tonnes to the eastern province of Gelderland. Despite this commitment in practice the waste flow is going to the own landfills because incineration tariffs are too high $[I]$. In the meantime the capacity of the two modern incinerators of Gelderland is not fully utilized. One is designed to handle 240000 tonnes of waste per year, but expects to incinerate only 70 to 80000 tonnes of waste in 1996. As a result of the lack of waste to be incinerated in the months January and February 1996 only, the deficit of this incinerator is 3 million guilders (fl). At present, the import of waste from Germany is seriously considered.

Like the northern provinces tried to make arrangements about incineration in Gelderland, the southern provinces did commit themselves to incinerators in the province of Noord-Holland. In 1995 a "put-or-pay" contract was drawn up, saying that each year 170000 tonnes of waste can be combusted against an attractive price of fl 155 per tonne. Only when less waste is going to be sent to the incinerator the tariff will rise substantially (ACP 1996). For a good understanding of the attractiveness of the incineration price: in 1993 tariffs ranged from fl 175 to $f 1305$ per tonne, while the weighted average was fl 225 per tonne (Admiraal 1994).

The long write-off periods of disposal plants are an obstacle to waste reductive policies of governments. For example, since April 1993 municipalities had to collect fruit, vegetables and garden waste separately. Cities like Amsterdam and Rotterdam, both main stockholders of incineration installations, were in opposition to this new obligation. For public authorities that are owners of such plants, waste reduction damages their own financial interests. Respondents assure that the financial necessity to use the relatively clean, but expensive incineration plant at its full capacity hinders financial and human investments in source reduction, recycling or other waste reducing activities [I].

Reduction of waste does not affect the raison d'etre of the organization, that is, providing the service of collecting waste. Therefore the goal of waste reduction may be on the whole compatible with the objectives of the public or private waste collecting organizations. As these input-oriented organizations have to pay for all extra waste they have to get rid of, reduction of waste supplied by consumers should result in a cost reduction. However, the situation changes completely when waste-collecting organizations are a part of the output-directed disposal or processing industry. In that 
situation the collection of waste is the most important activity in creating a constant flow of raw materials for the production process. The efforts of energy utilities to become part of the waste market in Germany may be questioned for this reason. There is is a trend towards getting involved in the disposal and processing side (the energy utilities have enormous financial resources), as well as in the collection side (investments in the Duales System Deutschland; Benzler et al. 1995; De Jong 1996).

\subsection{Who is providing valid information?}

It is in the interest of private collecting organizations to keep governmental policy makers in a situation of uncertainty about the amount and type of waste that will be released. Giving insights and figures could lead to a situation where it becomes possible to formulate deliberate waste policy. The actual situation is that the figures on which policy is based have limited value and the policies themselves have been wavering. For example, the expectation in the early nineties about capacity needed for incineration was an almost $200 \%$ growth within ten years (RIVM 1991). This became the official goal of policy (AOO 1992). Several projects for new facilities were started and a new physical planning instrument was introduced in a law specially designed to crush the expected local opposition against new incinerators (Wolsink 1994). In the meantime the figures have changed and the expectations about the capacity needed have been adjusted. Some of the new planned incinerators have already been cancelled (AOO 1995).

The CBS figures are based on surveys among municipalities and private disposers and the validity of these surveys has to be questioned. Municipalities themselves only have limited insight to the amount and type of waste they are handling. In many cases they can only give very rough estimates $[I]$. Private disposers often have a vested interest in keeping the figures diffuse $[I]$. Part of the problem is that the definitions of waste, type of waste and of processing (e.g. recycling) may vary, depending on the actor.

\subsection{Who is formulating policy?}

Another issue is that formulation and implementation of policy is connected to a certain administrative level. The responsibility of public authorities that deal with waste in general is limited to either the local, provincial or regional level. Private waste organizations may cross communal, provincial or even national boundaries and often they cannot be forced to implement the policy of public authorities because they operate at a larger scale than public authorities. This may result (and it actually has in certain cases) in discrepancies between predicted and actual amounts of waste in a certain area $[I]$.

It is in the interests of private waste collectors not to sign long-term contracts with waste processors. In this way they remain free to choose the cheapest processing option. One consequence is that forecasts of the amount of waste that will be generated in a certain area often fail to be correct. This may result in a deficit of incinerators and a tariff increase for contractors. From that perspective private collectors who are not contractually tied, possess "extra" waste. They can offer it to the processors that fail to utilize their full capacity, so these private collectors are in a position to negotiate incineration rates. Municipal collectors cannot operate that way, because they either have vested interests in incineration capacity or are bound to long term contracts. 
Over-capacity therefore leads to lower incineration rates for non-domestic solid waste $[I]$.

It is in the interests of the non-household "consumers" to keep the situation as it is. It is beneficial for them to keep waste handling and policy making authorities in a state of uncertainty about the quantities and composition of waste that will be released. Over-capacity causes lower incineration rates for non-domestic solid waste, because the rates for private waste collectors are agreed upon by bargaining and are significantly lower than the rates for contractors. More information and better planning of facilities will affect the favourable position of waste generating industries as may result in higher tariffs for waste processing and disposal [I]. Exchange of information will also give policy makers tools to formulate strict reduction goals in quantitative and qualitative sense.

Legal jurisdiction offers a basis for power for governmental organizations and other authorities, but it also restricts them. Public bodies participating in the waste sector fulfil a number of roles simultaneously, which causes entanglement:

(1) As representative of the law (function of control and issuing permits).

(2) As participants on waste market:

-when managing an incinerator they represent private and not only public interests; and

-when collecting waste they are victims of strategies chosen by disposers to be sure of waste input.

(3) As policy makers, serving public interests:

-the policy of the waste handling hierarchy (reduction, recycling, incineration, landfilling); and

-all types of policy directed at economic development, including the removal of obstructions to economic activity (e.g. high rates for waste handling or harsh regulations on waste composition and volume).

The relation between collection and disposal of waste is particularly crippling. Public bodies have to ensure the construction of an appropriate infrastructure for waste handling. In practice this means preventing combustible waste from being dumped. At the same time municipalities have the task of collecting domestic waste. The flow of waste to processing or disposal plants and the income of public authorities that collect household waste are closely linked. The tariffs that households have to pay for the collecting service should reflect the costs related to the collecting activity, including the marginal costs of disposal. At present the tariffs include costs made to facilitate disposal plants and making the long term exploitation feasible [I].

One of the bottle-necks in the current structure concerns the level on which waste handling activities take place. From the perspective of public authorities that have the responsibility to direct non-processable though combustible waste to incineration plants, it is indeed understandable that they want the disposal function to remain a task for utilities. The investments needed for incineration plants are higher than those needed for landfilling sites. As was argued before, the flow of waste to processing or disposal plants should have no links with the income of public authorities that collect household waste [I].

\section{Discussion}

Separating the different functions that actors perform within the waste sector, may have a positive effect on waste reduction. For example, benefits could be expected from 
drawing a line between the function of waste collection and the function of waste disposal. Other benefits could follow from separation of responsibilities regarding the construction of the infrastructure for waste handling on the one hand, and the formulation and implementation of waste policy on the other. The large circuit of consensus building with many actors involved before official policy acquires its form, is typical for The Netherlands. However, such "corporatism" in the formulation of waste policy has been recognized in other countries as well, for example in Finland (Hukkinen 1993).

In the Dutch waste sector there is no organization that is made explicitly responsible for waste reduction in any concrete form. Several governmental bodies attempt to take on the task of reducing waste alongside their efforts to create a convenient infrastructure for waste handling. Achieving this goal means that public authorities participating on the waste market interfere with public bodies operating as policy makers and upholders of the EMA.

A new policy line is the explicit attribution of responsibility to the waste-generating parties, preferably in the pre-consumption phase. In Germany, for example, this principle of producer responsibility for their products in the post-consuming phase is made concrete by the issuing of regulations. A packaging ordinance has given rise to the creation of a new system of waste handling for packaging waste, separate from the communal waste disposal system. The Grune Punkt system in Germany is paid for by the packaging producers involved (Fishbein 1994). The organization that is based on this system, Duales System Deutschland, is, however, showing a strong tendency toward monopoly (Benzler et al. 1995). Furthermore, the system is becoming under the influence of "processors" (energy utilities). At the same time there is resistance against it, because the system is developed for post-consumer processing instead of source reduction and pre-consumer recycling (Gandy 1994b).

In The Netherlands the principle of extending producer responsibility in an effort to reduce environmental impact, is becoming an issue as well. The national government and some industrials have signed an agreement on packaging. The covenant specifies recycling targets, leaving it to the industry how to meet these targets. Some efforts on other waste categories have also been made. For example new activities have been developed with regard to the automobile and electronics branches.

The different roles that governmental bodies have to play within the waste sector have been discussed before. The government has to represent environmental values as a public interest. A reliable waste collection and disposal system may be considered a public good. In most countries, authorities are trying to tighten their grip on the problem of waste flows. They have to find an answer to the question whether the best result can be expected from leaving waste handling activities as exclusive tasks for private organizations on a free market or whether participation by public authorities remains necessary. The market shows a tendency toward incineration instead of reduction and recycling, which includes a strong pressure (lobby) in most countries to "re-define" energy recovery as recycling (Gandy 1994a). However, the concentration of collection and disposal in one hand also causes a tendency towards incineration. The fact that this one hand is a public body does not improve the situation. An argument frequently put forward against the withdrawal of public bodies from the waste market, is the fear for the formation of monopolies or trust cartels, or that interference from organised crime in the waste market becomes hard to prevent (Van Traa 1996). On the other hand, it may become easier for authorities to exercise a supervisory role, when they are no longer participants in the waste market themselves. 


\section{Conclusion}

The general conclusion is that in the current structure of the waste sector in The Netherlands there are impediments discouraging waste generators from developing waste reduction activities. Conditions for collectors, processors and disposers affect the amount and type of generated waste. The network of organizations has its own dynamics which often follow a direction that is not in agreement with environmental policy goals, particularly waste reduction. The structure of the waste sector often creates entwined interests and as an unintended result of this, waste generation is often stimulated rather than restricted $[I]$. Actual incentives for waste reduction will only affect the quantity and type of waste when adjustments of the structure are enforced. These might be in changes in the relations between organizations or adjustments of the division of activities and the responsibilities of public authorities. Other options might be discarding old organizations and creating new ones for certain specified tasks.

As a result of this conclusion, the question arises whether the environmental objective of preventing waste generation could be achieved through structural changes. More research is needed to answer this question, particularly with regard to:

(1) The role of public authorities in investments for disposal facilities;

(2) The role of public authorities in formulating and implementing policy;

(3) Contracts to which participators in the waste market are bound;

(4) The tariff structure for waste collection, processing and disposal;

(5) The exchange of information between different participators in the waste sector; and

(6) The sources of data and the extent to which data about waste are available.

The impediments indicate the existence of certain elements in the structure of the waste sector which may be amenable to adaptation. Changes have to be directed at the creation of a new structure that gives waste reduction impulses from the end of the waste chain. From the perspective of realizing environmental goals, concentration of both input directed as well as output directed activities in one organization simultaneously, does not seem convenient. The two activities should be kept separate and be carried out by organizations that do not have entwined interests.

\section{Acknowledgement}

We would like to thank the anonymous reviewers for their constructive criticisms and supportive comments. This research is carried out at the Department of Environmental Science, University of Amsterdam, with financial support from the Dutch National Research Programme "Global Change".

\section{References}

ACP (1996) Waste Coordination Organization. ACP Nieuws (ACP news), March 1996.

Admiraal, D. B. (1994) Verkenning van kostprijzen van afvalverbrandingsinstallaties (Exploration of cost prices of incineration installations). AOO, Utrecht, Netherlands.

Anonymous (1994) Oostzaan blijft na praktijkproef afval wegen (Oostzaan continues weighing waste after experiment). Gemeentereiniging \& afvalmanagement 7/8, 271.

AOO (1992) Waste Management Council. Tienjarenprogramma afval 1992-2002 (Ten year programme for waste 1992-2002). Utrecht, Netherlands.

AOO (1994) Waste Management Council. Sturingsonderzoek AOO (Research on flow control). Utrecht, Netherlands. 
AOO (1995) Waste Management Council. Ontwerp tienjarenprogramma afval 1995-2005 (Concept ten year programme for waste 1995-2005). Utrecht, Netherlands.

AOO (1996) Waste Management Council. Verkenning voor de adviescommissie struktuurvisie afvalverwijdering (Exploration in favour of the advisory council outlook on the structure of wastehandling). Utrecht, Netherlands.

Benzler, G.., Halstrick-Schwenk, M., Klemmer, P. \& Lobbe, K. (1995) Wettbewerbskonformitat von Rucknameverpflichtungen im Abfallbereich (Equality in competition through take back ordinances on the field of waste). Rheinisch-Westfahlichen Instituts fur Wirtschaftsforschung, Essen, Germany.

Boons, F. (1996) Products within chains; an institutional analysis of the substitution of PVC piping and milk packaging. Workshop "naar een visie op kunststoffen in 2020" (Workshop "to an outlook on plastics in 2020"). Delft, Netherlands, January 17.

CBS (1993) Central Bureau of Statistics, Afvalstoffen; van gemeentewege ingezameld afval 1991 (Waste collected by the municipalities 1991). SDU publishers, The Hague, Netherlands.

Eurostat (1993) Basic statistics of the European Community. EU, Brussels/Luxembourg.

Fishbein, B. K. (1994) Germany, Garbage, and the Green Dot. Challenging the Throwaway Society. Inform, New York, U.S.A.

Gandy, M. (1994a) Recycling and the Politics of Urban Waste. Earthscan, London, U.K.

Gandy, M. (1994b) A comparative overview of recycling in London and Hamburg. Waste Management \& Research 12, 481-494.

Godfroy, A. J. A. (1990) Organisatie en omgeving (Organization and environment). Perspectieven op organisaties: organisatiepsychologie en -sociologie 2. Open Universteit, Heerlen, Netherlands.

Hukkinen, J. (1993) The way to Finnish waste: cognitive mapping of expert scenarios on waste management. XIII World Conference of World Futures Studies Federation, Turku, Finland 23-27 August 1993.

IEA (1994) International Energy Agency, Implementing Agreement on Demand-Side Management. IEA, Paris, France.

IPH (1994) Informatiecentrum Preventie en Hergebruik, Tariefdifferentiatie voor huishoudelijk afval (Tariff differentiation on domestic waste). AOO, Utrecht, Netherlands.

Johansen, S. \& Hoog, D. T. (1995) European Benefit/Cost (EUBC) analysis Methodology for Energy Efficiency Programs. Sustainability and the Reinvention of Government - A Challenge for Energy Efficiency (A. Persson, ed.). European Council for an Energy-Efficient Economy, Stockholm, Sweden, p. 9.

Jong, P. de \& Slingerland, S. (1996) Electricity consumption and waste reduction and demandside management activities in the Netherlands: similar problems, similar solutions? Greening of Industry Conference, Heidelberg, Germany, 24-27 November, 1996.

Jong, P. de \& Wolsink, M. (1993) De structuur van de Nederlandse afvalsector (The Structure of the Dutch Waste Sector). IVAM, University of Amsterdam, Netherlands.

Jong, P. de (1996) Producers responsibility in North Rhine-Westphalia (Germany), internal report. IVAM, University of Amsterdam, Netherlands.

Nadel, S. (1992) Utility demand side management experience and potential - a critical review. Annual Review of Energy and the Environment Vol. 17, Annual Review Inc., Palo Alto, CA, U.S.A.

Onck, A. van (1995) Tariefdifferentiatie heeft nog een lange weg te gaan (Tariff differentiation still has a long way to go). Gemeentereiniging \& afvalmanagement 1, 7-11.

Powell, J. (1993) Thermal plastics processing: is it recycling? Resource Recycling May 1995, $52-55$.

Pressman, J. L. \& Wildavski, A. (1984) Implementation (3rd ed.). University of California Press, Berkeley, CA, U.S.A.

Reijenga, F. A. (1989) Separate collection of compostables. BioCycle 30 (7), 62-64.

RIVM (1991) National Institute of Public Health and Environmental Protection, Nationale Milieuverkenning 2 1990-2010 (National Environmental Outlook 2 1990-2010). Samson H. D. Tjeenk Willink, Alphen aan den Rijn, Netherlands.

RIVM (1993) National Institute of Public Health and Environmental Protection, Nationale Milieuverkenning 3 1993-2015 (National Environmental Outlook 3 1993-2015). Samson H. D. Tjeenk Willink, Alphen aan den Rijn, Netherlands.

Rooy, P. de, Michael, A. \& Boogaard, H. (1996) Afvalinzameling in een onvolkomen markt (Waste collection in an Incomplete Market). VB-Marktgroep, Zwolle, Netherlands. 
Sabatier, P. A. \& Jenkins-Smith, H. C. (1993) Policy Change and Learning; an Advocacy Coalition Framework. Westview Press, Boulder, CO, U.S.A.

Tellegen, E. \& Gilijamse, W. (1995) Energy conservation and the Dutch energy sector. Tijdschrift voor Economische en Sociale Geografie $\mathbf{8 6}$ (4).

Traa, M. van (1996) Inzake opsporing; enquetecommissie opsporingsmethoden (Towards Tracing; Fact Finding Committee Tracing Methods). SDU Uitgevers, The Hague, Netherlands.

Van Ruiten Adviesbureau (1992) Recycling en afvalverwerking in Nederland (Recycling and waste disposal in the Netherlands). Bussum, Netherlands.

Verhoog, W. (1996) De weggegooide jaren van het afvalbeleid (The Wasted Years of Waste Policy). Milieuforum 3 (1) 8-9.

VROM (1989) Ministry of Housing, Physical Planning and Environment, Richtlijn verbranden 1989 (Guideline Incineration 1989). The Hague, Netherlands.

VROM (1990) Ministry of Housing, Physical Planning and Environment Netherlands Environmental Policy Plan plus. SDU publishers, The Hague, Netherlands.

Wolsink, M. (1994) Entanglement of interests and motives: assumptions behind the Nimbytheory on facility siting. Urban Studies 31, 851-866.

WRR (1992) Netherlands Scientific Council for Government Policy, Milieubeleid; stategie instrumenten en handhaafbaarheid (Environmental Policy; Strategy, Instruments and Enforcement). Sdu Publishers, The Hague, Netherlands. 